DR DAVID ROBIE is editor of

Pacific Journalism Review.

\section{Charlie Hebdo and the free speech conflict}

After Charlie Hebdo: Terror, Racism and Free Speech, edited by Gavan Titley, Des Freedman, Gholam Khiabany and Aurélien Mondon. London: Zed Books. 2017. 313 pages. ISBN 9781783609383

IN OCTOBER 2016, I returned to that stunning and iconic French eighth century monastery Mont St Michel-once also a post-Revolution jail for political prisoners - and was struck by the sight of a garrison of soldiers - part of the Vigipirate programme. ${ }^{1}$

Vigipirate has parallels with the US Homeland Security Advisor system and has been in place in various forms for almost 26 years, since Bush's Gulf War in 1991. Based on laws adopted in 1959 during the Algerian War of Independence, it was suspended for a while after the Gulf War and then introduced again in 1995 after a car bomb blew up outside a Jewish school in Lyon.

Vigipirate has since gone through various phases and updates, with the 1995 Paris Metro bombing, 2004 Madrid terror train attack and the 2005 London underground bombing. Official documents now designate the programme as 'permanent'.

About 7000 soldiers and 30,000

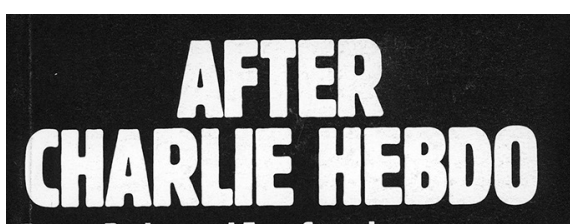

Terror, Racism and Free Speech

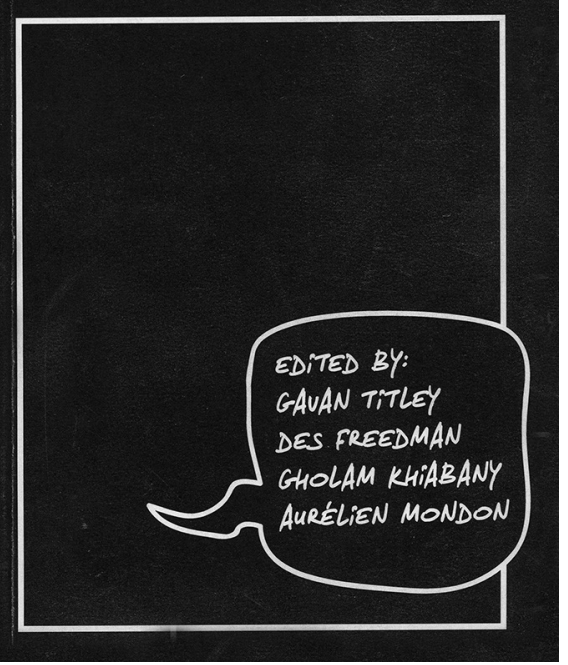

police and gendarmes are deployed at some 5000 'at risk' sites in France, costing an estimated $€ 1$ million a day.

The brutal and shocking attack on the office of left wing satirical magazine Charlie Hebdo on 7 January 2015 raised the profile of the Vigipirate campaign a few notches and drew millions onto the streets of France and around the world to protest and offer solidarity messages on social media under the hashtag \#JeSuisCharlie.

Indeed, I took part in a candlelight 'Charlie' vigil in Auckland organised by two young French photographers then living in New Zealand. At the time, the killing of 11 people (including a Muslim policeman) in the massacre at the magazine's office, which wiped out a generation of some 
of the most talented anti-establishment cartoonists in France, was portrayed by media and politicians as an assault on the freedom of expression fundamental to the French republic's philosophy of pluralism and democracy. It was seen as another outrageous attack in a 'war' between two rival civilisations that began with the September 11 attack on New York's Twin Towers in 2001 (p. 14).

The subsequent attack in Paris in November 2015, which killed 130 people, and the murder of 84 people by a rampaging truck driver in Nice in July 2016, heightened the sense of a 'war' in France even further. (Three months later, I paid homage at the intimate temporary memorial for the dead at Nice's Rotunda, just metres from where the massacre took place). However, the emotional and 'merciless' response by the then Hollande Socialist government of France, which declared that 'all acts of terror are now domestic 9/11s' (p. 14) left virtually no room in the news media or public discourse for considered reflection and balanced analysis. In fact, criticism of government policy or discussion about the anti-Islamic repression was regarded in France as tantamount to 'treason'.

This timely new book, After Charlie Hebdo: Terror, Racism and Free Speech, lifts the lid on the 'militarisation' of liberal values after the Paris attacks, exposing the extent of Islamophobia in France, as well as other countries in Europe such as Britain and Denmark, and the United States.

It also raises fundamental questions about the nature of national (and
Western) identity, the limits to freedom of speech and the role of both the traditional and social media.

This collection of 18 essays, and an Introduction about the transition of the symbolic from Charlie Hebdo to 'Charlie Hebdo', is divided into five sections: 1. The contested republic, 2. The long 'war on terror', 3. Media events and dynamics, 4 . The politics of free speech, and 5. Racism and antiracism in post-racial times.

Co-editor Gavan Titley describes the book as examining how the events round 'Charlie Hebdo' became a 'mediating object for a knot of political tensions, competing imaginaries and interpretative conflicts that have been taking shape and gathering force in European public spheres for several decades' (p. 2). He also explains that the book's engagement is not driven by a desire to rehash a normative theory on freedom of speech in our time, but to 'reclaim free speech as a radical political freedom' from the routinised spectacles in Western public cultures (p. 25).

In a chapter on media power and the framing of the Charlie Hebdo attacks, Des Freedman critiques the dominant and subjective Western media portrayal and interpretation of events and their causes. Noting that in spite of an 'industry of academic researchers, military strategists, civil servants and professional commentators', there was barely a 'vague consensus that terrorism involves the use of politically motivated violence imposed on innocent civilians by non-state groups' (p. 210).

As an illustration, Freedman quotes 
the Lebanon-based independent British journalist Robert Fisk in his description of 'nonsensical nomenclature', meaning that

if Muslims attack us, they are terrorists. If non-Muslims attack us, they are shooters. If Muslims attack other Muslims, they are attackers. (p. 211)

In a chapter on 'the meaning of Charlie' - the debate on the troubled French identity', Philippe Marlière engages with the French government's response to the killings, the symbols of the French republic, the state authorities in France, and critics such as demographer Emmanuel Todd, who contends in his 2015 book Qui Est Charlie? that the 'I am' and 'we are' demonstrators were not upholding the values of the 1789 Revolution - 'liberty, equality and fraternity' (Todd, 2015). Instead, the protesters were embodying the counter-revolution of 1815 , or the values of traditional Catholic France.

According to Marlière, the 'Charlie' protests began as a mass movement of 'citizens aggrieved and shocked by the atrocious killings'. However,

[i]t rapidly descended into a political football: the weak and unpopular socialist executive tried to regain the political initiative by promoting a kind of official and mandatory ' $\mathrm{Je}$ suis Charlie' line. It quickly became obvious to some that the 'Charlie' narrative meant much more than a robust defence of free speech and the 'right to blasphemy'.

Underneath the surface of the tribute to the dead, there was an authoritarian streak that ethnicised and stigmatised the Muslim population. The whole chain of events reinforced Islamophobic stereotypes. (p. 59)

As a result, the 5.1 million ( 8.8 percent) Muslims in France, mostly descendants from the Maghreb (North African) colonial legacy, were regarded 'with even more suspicion in different constituencies of the media and politics'.

Feminist author Christine Delphy (co-founder with Simone de Beauvoir of the journal Nouvelles Questions Féministes) offers a compelling examination of French colonialism in Algeria and its contemporary assaults on Muslim women represented by the hijab and burkini swimsuit controversies.

In her chapter, 'Race, caste and gender in France', she deconstructs the 'indigénat'status imposed on colonised peoples (dismantled in 1945) and its political and religious use in Algeria, where the vote of one Frenchman of European ancestry was 'worth' the vote of five Muslim Frenchmen.

She examines the pattern of oppression and discrimination in colonial times and the treatment of Muslims as 'inferior' and how the headscarf issue was a symbolic rebellion against the 'Republican model' - 'the boomerang effects of French society's blatant discrimination against these women' (p. 287).

Thus the veil affair opened the third act of this French tragedy: after the first act (oppression) came the second act (rebellion); and the third act is the repression of this rebellion. (p. 288) 
Delphy's comparison between the repression of protests against injustice in France and the US 'war without end' after $9 / 11$ is echoed by Abdellali Hajjat, who warns that harsh political reactions are steering France towards the adoption of a French 'Patriot Act' to add to the draconian terrorism laws. France - and much of the West - is in a double bind over defending liberal values.

\section{Note}

1. The term Vigipirate has nothing to do with 'piracy'. The programme name is a French acronym for vigilance et protection des installations contre les risques d'attentats terroriste à l'explosif ('vigilance and protection of installations against the risk of terrorist bombings).

\section{References}

Cross, T. (2015). Vigipirate, France's 'temporary' anti-terror plan celebrates $20^{\text {th }}$ birthday. Radio France Internationale (RFI). Retrieved from http://en.rfi.fr/ africa/20150908-vigipirate-francestemporary-anti-terror-plan-celebrates20th-birthday

Todd, E. (2015). Qui est Charlie? Sociologie d'une crise religieuse. Paris: Éditions du Seuil.
NOTED:

CHRISTOPHER THOMSON is codirector of the Arts Digital Lab at the University of Canterbury.

\section{Perfect media research text for undergraduates}

Digital Media and Society, by Simon Lindgren. London: Sage, 2017. 328 pages. ISBN 9781473925014

EROM the 'flamethrower squirrel' meme chosen for its cover to the many box-outs that define key questions, concepts and exercises for thinking, Simon Lindgren's Digital Media and Society is a punchy, engaging text pitched perfectly for undergraduates and others seeking an accessible introduction to contemporary media research.

Lindgren's book is divided into three sections: Theories, covering foundational concepts and contexts for thinking about digital media; Topics, covering deeper discussion of key topics in digital culture such as selfies, digital citizenship, and 'softwarisation'; and Tools, addressing the application of key 'traditional' and 'digital' research methods.

He builds bridges between tightly focused chapters, creating groups of two or three chapters on related topics which can be usefully read together. The style and choice of examples is accessible and encouraging for readers not yet exposed to much quantitative analysis. For instance, to explain 